REVISTA de

PEDAGOGIE

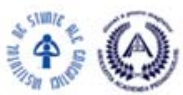

http://revped.ise.ro

Print ISSN 0034-8678; Online ISSN: 2559 - 639X

\title{
THE REFLECTIVE PRACTICE OF THE TEACHER - WHY IT IS NEEDED
}

PRACTICA REFLECTIVĂ A PROFESORULUI - O NECESITATE

Ioana STĂNCESCU, Luminiţa Mihaela DRĂGHICESCU, Ana-Maria Aurelia PETRESCU

\author{
Journal of Pedagogy, 2018 (1), 93 - 109 \\ https://doi.org/10.26755/RevPed/2018.1/93
}

The online version of this article can be found at: http://revped.ise.ro/category/2018-en/

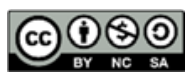

This work is licensed under the Creative Commons Attribution-NonCommercial-ShareAlike 4.0 International License.

To view a copy of this license, visit http://creativecommons.org/licenses/by-nc-sa/4.0/ or send a letter to Creative Commons, PO Box 1866, Mountain View, CA 94042, USA.

Published by:

\section{INSTITUTUL DE ȘTIINȚE ALE EDUCAȚIEI}

http://www.ise.ro/

Further information about Revista de Pedagogie - Journal of Pedagogy can be found at:

Editorial Policy: http://revped.ise.ro/editorial-policy/

Author Guidelines: http://revped.ise.ro/the-writer-guide-2/ 


\title{
PRACTICA REFLECTIVĂ A PROFESORULUI - O NECESITATE
}

\author{
Ioana Stăncescu* \\ Lumini a Mihaela Drăghicescu** \\ Ana-Maria Aurelia Petrescu*** \\ Departamentul pentru Pregătirea Personalului Didactic, \\ Universitatea ,Valahia” din Târgovişte \\ Târgovişte, România \\ stancescu_ioana@yahoo.com,lumidraghicescu@yahoo.com, \\ anapetrescu2007@yahoo.com
}

\section{Rezumat}

Lumea în care trăim este una în permanentă schimbare, restructurare, transformare. Sistemul educa ional trebuie să se racordeze la această lume şi să formeze viitori adul i responsabili, flexibili, creativi, care să răspundă adecvat solicitărilor din mediul social. Raportându-se la o astfel de intă, procesul de învă ământ urmăreşte formarea unor elevi care să dispună de competen e de comunicare, cognitive şi metacognitive, emo ionale, interculturale, investigative, digitale, civice etc.

Întrebarea care se pune, firesc, în această situa ie, este ce fel de profesori pot forma astfel de elevi. Dincolo de pregătirea ini ială şi continuă pentru profesia didactică, profesorii trebuie să în eleagă că eficientizarea activită ii didactice implică, în mod necesar, reflec ia asupra acesteia.

Prezentul studiu se focalizează pe conceptul de practică reflectivă, pe delimitarea unor etape ale acestui demers, pe identificarea unor metode şi instrumente specifice practicii reflective (jurnalele de reflec ie, înregistrările video şi audio ale lec iilor, feed-back-ul etc.) şi, respectiv, pe conturarea unui posibil model de personalitate al profesorului reflectiv, ce îşi subsumează următoarele dimensiuni: cunoaşterea de

\footnotetext{
* Lector univ. dr., Departamentul pentru Pregătirea Personalului Didactic (DPPD), Universitatea „Valahia”, Târgovişte.

** Conf. univ. dr., DPPD, Universitatea „Valahia”, Târgovişte.

***Conf. univ. dr., DPPD, Universitatea „Valahia”, Târgovişte.
} 
sine, cunoaşterea elevilor, cunoaşterea organiza iei şcolare, cunoaşterea curriculumului, cunoştin e în domeniul pedagogic.

Considerăm că practica reflectivă reprezintă o resursă valoroasă, încă insuficient exploatată, care poate aduce beneficii importante profesorului şi, implicit, elevilor, asigurând succesul şcolar şi, ulterior, profesional şi social.

Cuvinte-cheie: calitatea procesului educa ional, competen e, practică reflectivă, profesor reflectiv, stil didactic.

\section{Abstract}

The world we live in is one in permanent change, reorganization, transformation. The educational system has to connect to this world and to form future responsive, flexible, creative adults that respond appropriately to social demands. Referring to such a goal, the educational process aims the formation of students with important competences, like communicational, cognitive and metacognitive, emotional, intercultural, investigative, digital and civic competences.

The question in this situation is what kind of teachers can form such students. Beyond the initial and continuous training for the teaching profession, teachers need to understand that the efficiency of the didactic activity implies, necessarily, the reflection on it.

This study focuses on the concept of reflective practice, on delimiting the stages of this demarche, on identifying methods and instruments specific to reflective practice (reflection diary, video and audio recordings of the lessons, feed-back, etc.) and, respectively, on shaping a possible personality model of the reflective teacher, which subsumes the following dimensions: self-knowledge, knowledge of students, knowledge of the school organization, knowledge of the curriculum, knowledge in the pedagogical field.

We consider that reflective practice is a valuable resource, insufficiently used, which can bring important benefits to the teacher and, implicitly, to the students, towards the scholar success and, subsequently, the professional and social success.

Keywords: competences, quality of educational process, reflective practice, reflective teacher, teaching style. 


\section{Introducere}

Calitatea procesului educa ional reprezintă un factor decisiv pentru dezvoltarea individuală şi socială, deopotrivă. Există, la nivelul Comunită ii Europene, un interes crescut pentru asigurarea calită ii în educa ie, conştientizându-se faptul că aceasta este o for ă motrice a competitivită ii, a creşterii în orice domeniu de activitate. Cei de care depinde, însă, în mod hotărâtor, calitatea educa iei sunt profesorii. Numeroasele studii şi rapoarte ${ }^{1}$ realizate în ultimii ani, indică un declin evident în ceea ce priveşte competen ele de predare ale profesorilor şi atractivitatea acestei profesii, corelat $\mathrm{cu}$ deficien e ale procesului de formare a cadrelor didactice. În acest sens, recomandările Comisiei Europene vizează atât formarea ini ială, cât şi formarea continuă a profesorilor şi subliniază importan a promovării, în toate statele membre, a politicilor axate pe o cultură a practicii şi cercetării reflective în cadrul profesiei didactice (Comisia Europeană, 2007).

Pentru diseminarea şi implementarea unor astfel de politici, pasul decisiv este a-i determina pe profesori să în eleagă că îmbunătă irea continuă a calită ii procesului educa ional implică, în primul rând, reflec ia asupra acestuia. Practica reflectivă trebuie să devină o componentă intrinsecă a practicilor educa ionale, situa ie care reclamă instrumentarea cadrelor didactice cu un set de cunoştin e şi abilită i necesare pentru acest demers.

\section{Ce este practica reflectivă?}

\subsection{Cadru conceptual}

Conceptul practică reflectivă este complex, situat încă într-o zonă de ambiguitate, conferin-du-i-se o serie de interpretări, în func ie de care se conturează diverse modele de abordare şi modalită i de instruire a profesorilor, cu scopul de a facilita achizi ionarea abilită ilor specifice. Cel căruia îi datorăm introducerea no iunii ,,predare reflectivă" (reflective teaching) şi deschiderea unui nou câmp de cercetare, cu efecte benefice atât în planul asigurării calită ii în educa ie, în general, cât şi în cel al formării ini iale şi al dezvoltării profesionale continue a cadrelor didactice, în special, este John Dewey (1933, 
în Pollard, 2008). În optica sa, reflec ia este ,,raportare activă, consecventă/ continuă şi atentă la orice convingere sau formă de cunoaştere, din perspectiva argumentelor care o sus in şi a concluziilor ulterioare către care aceasta tinde" (1933, în Johnson, 2002, p. 74).

Pentru clarificarea conceptului ,,predare reflectivă”, Dewey aduce în prim planul aten iei două no iuni aflate în antiteză: ,,ac iunea rutinieră” şi ,,ac iunea reflectivă" (1933, în Pollard, 2008). Astfel, ac iunea rutinieră a educatorului este bazată pe elemente cum ar fi: tradi ia, obişnuin ele, autoritatea, reglementările şi aşteptările institu ionale. Ac iunea rutinieră este, mai degrabă, statică şi nu are impact asupra priorită ilor şi circumstan elor procesului educa ional. Ac iunea reflectivă, pe de altă parte, implică dorin a de angajare în demersuri de autoevaluare şi autodezvoltare, ce trebuie să devină constante ale practicii profesionale a cadrului didactic. Ea solicită, de asemenea, din partea profesorilor, flexibilitate, realizarea unor analize riguroase şi conştientizare socială.

Impulsiona i de studiile lui Dewey, mul i cercetători au continuat investiga iile centrate pe problematica ,reflec iei” în procesul educa ional, abordând acest aspect din perspective multiple, dovadă fiind varietatea de termeni utiliza i: practică reflectivă, predare reflectivă, reflec ie critică, gândire reflectivă, reflexivitate etc.

Schön (1983, în Pollard, Gougoulis, 2002, p. 1) descrie ,practica reflectivă” ca fiind o activitate profesională în care practicienii reflectează atât în timpul ac iunii (reflection-in-action), cât şi după finalizarea acesteia (reflectionon-action). Reflec ia devine, astfel, calea sine qua non pentru creşterea eficien ei acelei ac iuni/activită i. În concep ia lui Schön, ini ial, reflec ia apare pe parcursul derulării activită ii didactice şi constă în observarea şi monitorizarea propriilor ac iuni, simultan cu realizarea lor şi consemnarea imediată a unor aspecte constatate. Reflec ia din timpul activită ii asigură reglarea/optimizarea acesteia din mers.

Reflec ia continuă, însă, şi după finalizarea procesului didactic, moment în care profesorul poate acorda o aten ie sporită unei analize complexe, fără necesitatea de a ac iona imediat, şi poate primi asisten ă şi sprijin din partea altor profesori, valorificându-se experien ele acestora. 
Pollard (2008, p. 14) prezintă şi explică şapte caracteristici fundamentale ale practicii reflective:

1. implică o preocupare activă pentru obiectivele educa ionale şi pentru rezultatele ob inute;

2. este aplicată într-un proces ciclic sau în spirală, în care profesorul monitorizează, evaluează şi îşi reconsideră, în mod continuu, propriile practici educa ionale;

3. solicită competen e de cunoaştere şi utilizare a metodelor de realizare a cercetării-ac iune în clasa de elevi, în vederea optimizării propriului stil didactic;

4. solicită, din partea profesorului, responsabilitate, deschidere şi implicare totală în activitate;

5. se bazează pe emiterea unor judecă i de valoare de către profesor, fundamentate pe informa iile ob inute din cercetarea realizată la nivelul clasei şi pe coroborarea acestora cu cele rezultate din alte cercetări;

6. predarea reflectivă, dezvoltarea profesională şi desăvârşirea personală a profesorului sunt sus inute şi amplificate de colaborarea şi dialogul cu ceilal i profesori;

7. practica reflectivă abilitează profesorii să medieze creativ diferitele contexte de învă are.

Zeichner şi Liston apreciază că ,predarea reflectivă presupune o recunoaştere, examinare şi ruminare asupra implica iilor convingerilor, experien elor, atitudinilor, cunoştin elor şi valorilor, precum şi ale oportunită ilor şi constrângerilor generate de condi iile sociale în care profesorul func ionează" (Zeichner, \& Liston, 1996, în Johnson, 2002, p. 75).

Ghaye propune ca profesorul angajat în reflec ia asupra propriilor practici didactice să se ghideze după următoarele întrebări: 1. valori: Cum trebuie să ac ionez?; 2. aşteptări: Ce trebuie să fac?; 3. context: Ce pot realiza în condi iile date?; 4. decizie: Ac iunea mea este justificată?; 5. op iune: Puteam să fac ceva mai bine sau diferit?; 6. judecată: Cât de mult succes a avut ceea ce am făcut?; 7. punct forte: Ce aspect poate fi maximizat/ valorizat mai bine data viitoare?; 8. învă are: Cine şi ce a învă at?; 9. voce: A cui voce a fost auzită şi a cui nu?; 10. cunoştin e: Ce cunoştin e merită a fi ştiute şi de ce? (2010, în Zalipour, 2015, p. 4). 
Raportându-ne la toate aceste perspective de abordare prezentate anterior, putem concluziona că practica reflectivă a profesorului nu este un demers facil, ci, dimpotrivă, unul complex, care antrenează toate resursele profesorului - cognitive, metodologice, emo ionale etc. - în direc ia îmbunătă irii propriei activită i didactice, cu efecte benefice asupra procesului de învă are şi asupra rezultatelor acestuia.

Sintetic, practica reflectivă a profesorului reprezintă o analiză conştientă, profundă, asumată, responsabilă a activită ii didactice, pe parcursul şi la finalul acesteia, urmată de adoptarea unor decizii informate în ceea ce priveşte controlul şi reglarea ei, pe direc ia realizării obiectivelor educa ionale propuse. Pentru a deveni practician reflectiv, profesorul trebuie să se angajeze într-un demers etapizat şi să utilizeze metode şi instrumente specifice.

\subsection{Etape ale practicii reflective}

Zeichner şi Liston (1996, în Finlay, 2008, p. 4) decelează cinci etape distincte ale practicii reflective:

1. reflec ia rapidă: ac iunea imediată, continuă, automată a profesorului;

2. remedierea: adoptarea deciziei de a schimba propriul comportament ca răspuns la feed-back-ul elevilor;

3. revizuirea: analiza, discu ia sau consemnarea unor aprecieri/judecă i de valoare vizând aspecte specifice propriului stil de predare;

4. cercetarea: exersarea unei gândiri/reflec ii mai sistematică şi mai îndelungată în timp, sus inută de documentare/colectare de informa ii ştiin ifice relevante;

5. reteoretizarea şi reformularea: examinarea critică a propriilor practici şi convingeri/concep ii din perspectiva teoriilor pedagogice.

Pollard (2008, p. 18), consecvent cu modul de abordare a predării reflective conturat de John Dewey, propune ca stadii specifice acestui demers: 1. planificarea activită ii; 2 . formularea de ipoteze/previziuni; 3 . ac iunea; 4. colectarea datelor; 5. analiza datelor; 6. reflec ia.

Parcurgerea etapelor men ionate îl conduce pe profesor la revizuirea propriilor practici educa ionale, la o mai bună proiectare a unei noi secven e a procesului 
didactic. Ac iunile profesorului se încadrează într-un demers dinamic, care trebuie să treacă prin cicluri succesive sau printr-un proces în spirală, generând, astfel, o predare la standarde înalte de calitate.

O altă perspectivă asupra stadiilor pe care le presupune reflec ia realizată de către profesor, o prezintă Quinn (2000, în Finlay, 2008, p. 8). Astfel, reflec ia implică următoarele trei procese: 1 retrospec ia-analiza atentă a unor situa ii şi experien e trecute; 2. autoevaluarea - analiza şi evaluarea critică a ac iunilor şi trăirilor emo ionale asociate cu experien ele traversate, valorificând perspectivele teoretice relevante; 3 . reorientarea - utilizarea rezultatelor autoevaluării pentru a influen a viitoarele abordări ale unor experien e sau situa ii similare.

Analizând etapele practicii reflective, aşa cum le descriu autorii mai sus men iona i, putem constata că aceasta este un proces multifazial, complex, ce solicită din partea profesorului variate competen e: de planificare, de colectare şi interpretare a datelor, de adoptare a deciziilor oportune, menite să conducă la optimizarea activită ii educa ionale.

\subsection{Metode şi instrumente specifice practicii reflective}

O persoană care reflectează la practicile sale nu se concentrează numai asupra ac iunilor şi evenimentelor trecute, ci abordează conştient şi emo iile, experien ele, ac iunile şi reac iile la acestea, adăugând aceste informa ii la setul său de cunoştin e şi valorificându-le pentru a accede la un nivel mai înalt de în elegere (P. Mathew, P. Mathew, \& Peechattu, 2017, p. 127). Pentru o asemenea abordare, un profesor - practician reflectiv - trebuie să utilizeze o serie de metode, tehnici şi instrumente adecvate scopului propus şi relevante pentru evaluarea propriilor practici de predare.

Consultând literatura de specialitate, remarcăm faptul că o serie de autori (Shepherd, 2006; Tompkins, 2009; Trif, \& Popescu, 2013; Selmoa, \& Orsenigo, 2014; Leijena et al., 2014; Mathew, Mathew, \& Peechattu, 2017 etc.) îşi concentrează preocupările în direc ia prefigurării unei metodologii / tehnologii specifice practicii reflective. În urma analizei metodelor, tehnicilor şi instrumentelor descrise de aceştia, prezentăm câteva dintre ele, cu 
men iunea că pot fi aplicate de către orice profesor, indiferent de experien a didactică:

1. Jurnalele de predare / practică reflectivă / jurnalele de reflec ie după fiecare lec ie, profesorul poate consemna ac iunile, reac iile, emo iile sale şi ale elevilor; poate prezenta, într-o manieră descriptivă, activitatea desfăşurată. Informa iile înregistrate în acest mod sunt „supuse” apoi unui proces de reflec ie, focalizat pe analiza practicilor de predare, a stilului didactic adoptat etc., din perspectiva eficien ei lor. Jurnalul este un instrument care asigură corelarea teoriilor şi paradigmelor specifice domeniului ştiin elor educa iei cu practica educa ională. Realizarea jurnalului de reflec ie solicită, din partea cadrului didactic, disponibilitatea de a investi, constant, timp şi efort. Se pot utiliza diferite tipuri de jurnale. Astfel, Hobson (1996, în Tompkins, 2009, p. 8) propune completarea unui jurnal de reflec ie cu intrare dublă, în care consemnarea descriptivă a informa iilor despre o activitate sus inută este separată de reflec ii. De exemplu, pe partea stângă a paginii se înregistrează informa iile, în timp ce reflec iile sunt plasate pe partea dreaptă.

Shepherd (2006, în Tompkins, 2009, p. 8) consideră că, pentru a facilita în elegerea aprofundată a situa iilor de instruire/contextelor instruc ionale, jurnalul de reflec ie trebuie construit prin raportare la următoarele patru întrebări: Cum mă simt în legătură cu acest lucru / această situa ie?; Ce cred despre aceasta?; Ce am învă at din acest lucru / această situa ie? şi Cum voi proceda / ce ac iuni voi realiza ca urmare a lec iilor învă ate?. Ulterior, pentru a-l determina pe profesor să conştientizeze schimbarea survenită în urma reflec iei, Shepherd a adăugat alte două întrebări: Ce am învă at din ceea ce am făcut? şi Ce am făcut cu ceea ce am învă at?

Apreciem că beneficiul major al utilizării jurnalelor de reflec ie rezidă în asocierea permanentă a propriilor practici educa ionale ale profesorului, cu teoriile pedagogice, cu dezvoltările recente în domeniul ştiin elor educa iei. Pe baza consemnărilor din jurnal, profesorul poate analiza şi argumenta deciziile educa ionale adoptate prin raportare la propria cunoaştere pedagogică şi îşi poate defini, astfel, mult mai clar, concep ia pedagogică personală, ce are un rol important în proiectarea şi realizarea demersului didactic.

2. Inregistrările video sau audio ale lec iilor - furnizează informa ii utile pentru reflec ie, îl ajută pe profesor să conştientizeze diferite aspecte 
specifice procesului de predare. În clasă, concentrat, în mod special, pe anumite dimensiuni ale activită ii didactice, profesorul poate pierde din vedere factori/variabile cu impact asupra elevilor / procesului propriu-zis / rezultatelor vizate. Audiind/vizualizând ce s-a întâmplat pe parcursul lec iei, gândirea sa reflectivă este stimulată, poate decela mai uşor punctele nevralgice şi poate reflecta asupra lor, cu scopul de a optimiza, ulterior, procesul de predare-învă are-evaluare.

Inregistrările audio pot oferi informa ii relevante pentru procesul comunica ional: Cât timp consumi pentru a comunica elevilor anumite con inuturi informa ionale?; Cât de accesibil este modul în care comunici?; Sunt clare instruc iunile şi explica iile?; Cât timp aloci pentru dialog/conversa ie?; Cum răspunzi la întrebările adresate de elevi? etc.

Inregistrările video pot fi utile în analiza comportamentului profesorului: Cum te pozi ionezi în spa iul clasei?; Cu cine interac ionezi?; Cum gestionezi interac iunile cu elevii?; Cum te apropii de elevi? etc.

Chiar dacă valorificarea înregistrărilor video sau audio, în contextul practicii reflective, presupune costuri suplimentare pentru şcoli, beneficiile acestora sunt evidente. Audiind sau vizionând lec ia înregistrată, profesorul poate conştientiza, în special, aspecte referitoare la comunicarea şi interac iunea cu elevii şi îşi poate optimiza propriile competen e de comunicare (verbală, paraverbală, nonverbală) şi interac iune socială.

3. Feed-back-ul elevilor - opiniile şi percep iile elevilor pot completa informa iile despre o lec ie sus inută, orientând procesul de reflec ie către o altă perspectivă, diferită, ce se poate dovedi extrem de valoroasă pentru îmbunătă irea stilului didactic al profesorului şi eficientizarea activită ii. Se poate solicita elevilor feed-back prin intermediul unui chestionar, administrat după finalizarea lec iei.

Feed-back-ul, indiferent de tipul acestuia - verbal sau nonverbal, spre exemplu - este extrem de util profesorului, stimulându-l să-şi dezvolte capacitatea empatică şi să analizeze/evalueze demersul didactic şi din perspectiva elevilor. De multe ori, opiniile, reac iile elevilor la o anumită experien ă de învă are construită de către profesor, se pot constitui în puncte de plecare pentru optimizarea viitoarelor activită i de instruire.

4. Cercetarea-ac iune - rezidă în decelarea unei probleme sau situa ii, relevante pentru procesul predării, pe baza informa iilor înregistrate/ recoltate. Jurnalul de reflec ie poate servi ca punct de plecare în acest 
demers. Cercetarea-ac iune completează în elegerea de către profesor, la un alt nivel, a ceea ce se întâmplă în sala de clasă, ajutându-l să identifice probleme comune, să formuleze ipoteze cu privire la posibilele cauze sau factori declanşatori ai unei situa ii, să contureze solu ii, să dezvolte un plan de măsuri, să îl implementeze şi să evalueze apoi rezultatele ob inute, împreună cu al i colegi. Cercetarea-ac iune se bazează pe reflec ie şi cooperare.

Apreciem că un demers de cercetare-ac iune se poate solda cu efecte vizibile în planul îmbunătă irii practicilor educa ionale ale profesorului şi, implicit, al rezultatelor şcolare. Astfel, cercetarea-ac iune:

- facilitează conştientizarea complexită ii profesiei didactice, a rolurilor şi abilită ilor specifice pe care trebuie să le exercite, respectiv să le demonstreze orice profesor;

- asigură în elegerea, la un nivel mai profund, a importan ei activită ii de proiectare didactică;

- permite identificarea punctelor forte şi a punctelor slabe ale propriei conduite didactice şi motivează profesorul pentru a se implica, în mod constant, în activită i de dezvoltare profesională;

- permite dezvoltarea gândirii critice;

- oferă ocazia de a stabili corela ii între pregătirea teoretică şi cea practică, de a reflecta asupra a ceea ce ştii, precum şi asupra a ceea ce ştii să faci efectiv în activitatea cu elevii;

- asigură contexte favorabile interac iunii, împărtăşirii propriilor experien e, opinii, idei, emo ii etc.;

- oferă ocazia îmbogă irii propriului repertoriu de metode, procedee şi tehnici de predare, cu impact asupra calită ii actului didactic.

Concluzionând, considerăm că utilizarea unor strategii adecvate pentru reflec ia asupra practicilor educa ionale reprezintă premisa unui proces de reglare/îmbunătă ire/eficientizare a activită ii didactice, cu şanse de reuşită.

\section{Un posibil profil de personalitate al profesorului reflectiv}

În deplin acord cu Larrivée, apreciem că, ,exceptând cazul în care profesorii dezvoltă practica reflec iei critice, ei rămân prinşi în capcana judecă ilor 
neexaminate, a interpretărilor, asump iilor şi aşteptărilor. Abordarea predării ca practică reflectivă implică fuziunea credin elor şi valorilor personale într-o identitate profesională" (Larrivée, 2000, în Finlay, 2008, p. 2).

Încercarea de a contura un posibil portret al profesorului reflectiv şi de a delimita trăsături specifice identită ii sale profesionale reprezintă o ac iune complexă, întrucât presupune raportarea la o serie de elemente specifice spa iului educa ional.

Specialiştii din Universitatea Southern Indiana au sintetizat un astfel de ,,portret”, materializat în figura de mai jos:

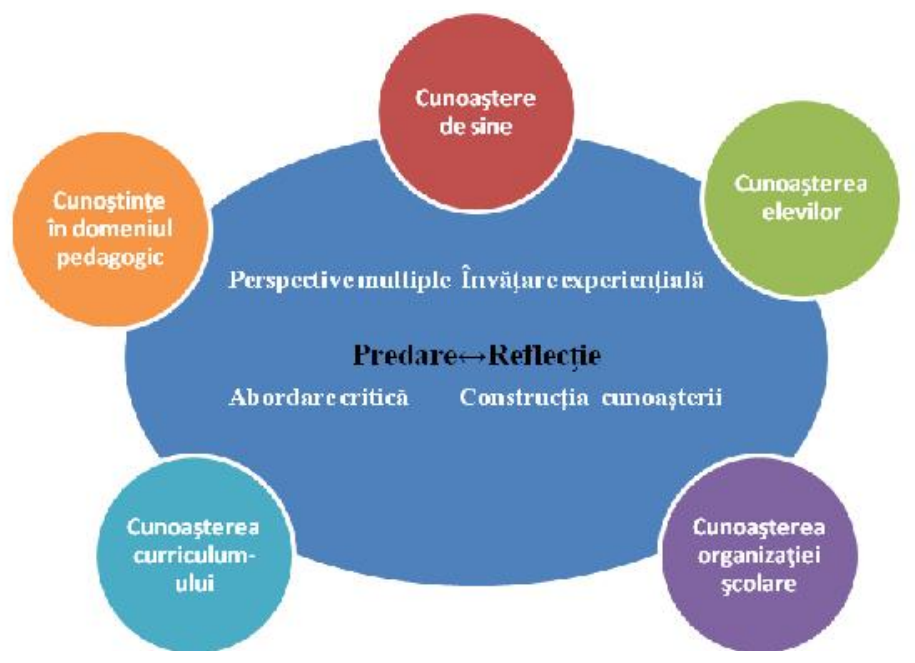

Figura nr. 1. Modelul profesorului reflectiv (University of Southern Indiana) Sursa: http://www.usi.edu/science/teacher-education/student-resources/ reflective-teacher-model/ 
Tabelul nr. 1. Modelul profesorului reflectiv

\begin{tabular}{|c|c|}
\hline \multicolumn{2}{|c|}{ Modelul profesorului reflectiv } \\
\hline Cunoaştere de sine & $\begin{array}{c}\text { Viziune şi valori personale } \\
\text { Competen e interpersonale }\end{array}$ \\
\hline Cunoaşterea elevilor & $\begin{array}{c}\text { Dezvoltarea copilului/adolescentului } \\
\text { Experien e anterioare } \\
\text { Diversitate culturală } \\
\text { Teorii ale învă ării } \\
\text { Valori }\end{array}$ \\
\hline $\begin{array}{c}\text { Cunoaşterea organiza iei } \\
\text { şcolare }\end{array}$ & Specificul şi func ionarea şcolilor \\
\hline $\begin{array}{c}\text { Cunoaşterea curriculum-ului } \\
\text { Cunoştin e în domeniul } \\
\text { pedagogic }\end{array}$ & Interdisciplinaritate \\
& Specificul disciplinelor de învă ământ \\
& Educa ie liberală \\
\hline Curriculum centrat pe elev \\
Contextul clasei de elevi/mediul de învă are \\
Instruire \\
Evaluare \\
Managementul clasei de elevi \\
Tehnologie didactică
\end{tabular}

Sursa: http://www.usi.edu/science/teacher-education/student-resources/ reflective-teacher-model/

Considerăm că acest model, cu anumite completări care se impun, se poate constitui în punct de plecare pentru definirea standardelor specifice profesiei didactice. Astfel, prin raportare la fiecare dimensiune a modelului profesorului reflectiv, pot fi decelate competen e profesionale specifice. Vom realiza, în cele ce urmează, o analiză succintă a componentelor acestuia, eviden iind modul în care profesorul trebuie să se raporteze la fiecare în parte:

a. Cunoaştere de sine - un profesor preocupat permanent de calitatea procesului educa ional îşi va orienta reflec ia mai întâi către sine, defininduşi propria viziune asupra educa iei, asupra cunoaşterii, propria concep ie pedagogică, ,,alimentată”, desigur, de paradigmele specifice domeniului educa ional, de teoriile cu privire la educa ie. Aceste elemente constitutive ale identită ii sale profesionale sunt infuzate de valori personale şi vor influen a în mod decisiv practicile educa ionale, stilul didactic al profesorului, modul în care va interac iona cu elevii;

b. Cunoaşterea elevilor - orice demers didactic se construieşte prin raportare la particularită ile educabililor. Un profesor reflectiv va analiza 
Şi va stabili eficien a activită ii sale în func ie de o serie de repere precum: caracteristici psihologice de vârstă şi individuale ale elevilor, specificul învă ării la diferite vârste, prerechizitele elevilor, background-ul cultural al acestora etc.;

c. Cunoaşterea organiza iei şcolare - institu ia de învă ământ, cu elementele ei de specificitate, cu valorile pe care le promovează, integrate organic în cultura organiza ională, şi care influen ează ceea ce se întâmplă efectiv în clasa de elevi, reprezintă un alt aspect pe care se va focaliza reflec ia profesorului;

d. Cunoaşterea curriculum-ului - având o cultură pedagogică solidă, un profesor reflectiv va în elege că abordarea unei teme din perspectivă monodisciplinară / intradisciplinară este, astăzi, un demers ce trebuie abandonat. Interdisciplinaritatea, pluridisciplinaritatea, transdisciplinaritatea trebuie să se regăsească, din ce în ce mai mult, în ac iunile de organizare a curriculum-ului şi apoi de diseminare a acestuia către elevi;

e. Cunoştin e în domeniul pedagogic - profesorul reflectiv valorizează şi conştientizează importan a pregătirii sale pedagogice, supunând permanent analizei propriile competen e metodologice, manageriale, de evaluare, de comunicare, de interac iune socială etc.

Modelul descris plasează accentul pe filosofia procesului de formare / dezvoltare a personalită ii didactice a profesorului reflectiv, definit prin următoarele caracteristici:

1. Este conştient şi activ - ini iază instruirea cunoscând nevoile elevilor şi o orientează spre ac iuni sau convingeri menite să rezolve întrebările, tensiunile şi curiozită ile care au declanşat procesul de cercetare/ investigare al elevilor;

2. Este deschis către individualitatea elevilor - conştientizează faptul că procesul social al educa iei implică personalizare, individualizare şi elevii nu pot fi constrânşi să devină coparticipan i la acest proces, ci aceasta trebuie să fie alegerea lor;

3. Este preocupat de interesele, nevoile şi perspectivele/modul în care in eleg elevii-valorizează şi îmbunătă eşte permanent rela iile cu elevii, acceptând şi recunoscând capacitatea acestora de a fi, la rândul lor, „gânditori reflectivi”; tratează cu seriozitate problemele, ipotezele şi concluziile formulate de elevi; 
4. Este răbdător - în elege şi acceptă că este nevoie de timp pentru ca ideile să fie dezvoltate, delimitate în mod acurat şi evaluate. Durata unei instruiri reflective poate fi de câteva zile, săptămâni sau ani, dacă există preocupare pentru realizarea scopului propus;

5. Este flexibil -acceptă divergen ele de abordare / de opinii şi schimbările tehnologice; încearcă să extindă op iunile/perspectivele, mai degrabă decât să le limiteze. Manifestă deschidere fa ă de metodele şi punctele de vedere alternative şi este dispus să-şi schimbe opinia/convingerea/modul de a gândi;

6. Este o persoană care înva ă continuu/investeşte în învă are - se implică în demersuri de explorare, investigare şi creştere personală, plasând sub semnul îndoielii propriile concluzii/convingeri/practici, deoarece îşi conştientizează statutul de persoană care înva ă continuu;

7. Este conştient de necesitatea autoevaluării, introspec iei - tratează propriul proces de gândire, decizie ca parte a domeniului de cercetare; conştientizează ipotezele, logica, alegerile, priorită ile şi concluziile personale;

8. Este atent atât la scopuri, cât şi la mijloace - se gândeşte la impactul deciziilor sale asupra vie ii copiilor pe care îi înva ă; reflectează nu numai la mijloace (Cum pot face acest lucru mai bine?), ci şi la scopuri (De ce fac acest lucru?).

(adaptare după Modelul profesorului reflectiv, propus în cadrul Universită ii Southern Indiana, http://www.usi.edu/science/teacher-education/studentresources/reflective-teacher-model/).

Orice educator, conştient de valoarea de model a personalită ii sale, este necesar să îşi formeze / să îşi dezvolte trăsăturile şi abilită ile circumscrise profilului de personalitate al profesorului reflectiv, demonstrând astfel, o dată în plus, devotamentul fa ă de profesia didactică, ataşamentul şi grija manifestate în rela ia cu elevii săi şi în elegerea profundă a misiunii sale.

\section{Concluzii}

În contextul preocupărilor de a asigura calitatea procesului educa ional, angajarea într-o practică reflectivă autentică, bazată pe valorificarea tuturor competen elor profesionale şi transversale ale profesorilor, nu poate avea 
decât efecte pozitive, atât în planul procesului de predare-învă are-evaluare, cât şi în cel al dezvoltării profesionale şi personale continue. Este necesar ca practica reflectivă să devină o dimensiune a identită ii profesionale a cadrelor didactice, integrată organic în arhiva competen elor şi a propriilor practici educa ionale.

De altfel, în consonan ă cu punctul de vedere exprimat de Krause (2004, în Clarke, 2007, p. 3), apreciem că reflec ia orientează profesorul în toate ac iunile şi deciziile sale: în faza de planificare a demersului didactic, reflec ia poate ajuta la adoptarea deciziilor specifice acestui moment. În etapa de realizare a lec iei, reflec ia are un rol important în monitorizarea progresului acesteia, în abordarea flexibilă, suplă a situa iilor de instruire şi în adaptarea strategiilor didactice la particularită ile contextului educa ional. În etapa de evaluare, reflec ia îl ajută pe profesor să stabilească punctele forte, elementele izbutite ale lec iei, precum şi punctele slabe, disfunc ionalită ile procesului didactic, dar şi cauzele acestora. Rezultatele reflec iei sunt, apoi, valorificate pentru proiectarea următorului demers de instruire. Se creează, astfel, un proces de ac iune ciclică, obiectivat în îmbunătă irea/optimizarea stilului didactic al profesorului, a competen elor sale psihopedagogice, în creşterea randamentului şcolar şi a eficien ei actului educa ional, în general.

Punctele de vedere teoretice prezentate, analizate şi interpretate în studiul de fa ă, fără preten ia exhaustivită ii, pot deveni fundamente pentru realizarea unor demersuri de cercetare aplicativă care să vizeze etapele practicii reflective, utilitatea şi beneficiile metodelor şi intrumentelor specifice şi completarea modelului de personalitate a profesorului reflectiv. Toate acestea pentru că avem convingerea că numai printr-o reflec ie atentă asupra practicilor educa ionale, cadrele didactice pot conştientiza aspectele forte şi pe cele vulnerabile ale propriului stil didactic, ale propriilor competen e şi pot opera schimbări oportune, menite să contribuie nu numai la dezvoltarea lor profesională, ci, implicit, la îmbunătă irea calită ii procesului educa ional².

\section{Note}

A se consulta următoarele documente: Teachers Matter: Attracting, Developing And Retaining Effective Teachers, OECD, 2005; Education: Communication on 
the quality of teacher education, 2007; Şi cadrele didactice au nevoie de o formare de calitate! Comisia propune îmbunătă irea calită ii formării cadrelor didactice în Uniunea Europeană, Comisia Europeană, 2007; TALIS 2013 Results: An International Perspective on Teaching and Learning, OECD, 2014; Raport na ional. Analiza mediului educational din România, CNEE, 2014; Profesia de cadru didactic în Europa: Practicile, Percep iile şi politicile, Eurydice, 2015; Educa ie, bună guvernare şi securitate na ională, Bădescu, G., Sinea, A., \& Jiglău, G. (coord.), 2016; Dezvoltarea şcolilor şi calitatea excelentă a predării pentru un început bun în via ă, Comisia Europeană, 2017; Studii OCDE privind evaluarea şi examinarea în domeniul educa iei. România 2017, OECD, 2017; Cadre Didactice - Raport de ară, SABER, 2017; Monitorul educa iei şi formării. România, Comisia Europeană, 2017 etc.

2 Contribu ia autorilor la elaborarea lucrării este egală.

\section{Referin e}

- Clarke, P. A. J. (2007). Reflective Teaching Model: A Tool for Motivation, Collaboration, Self-reflection, and Innovation in Learning. Georgia State University. https://www.researchgate.net/publication/251733901_Reflective_ Teaching_Model_A_Tool_for_Motivation_Collaboration_Self-reflection_and_ Innovation_in_Learning.

- Comisia Europeană. (2007). Education: Communication on the Quality of Teacher Education / FAQ, MEMO/07/320, Bruxelles. europa.eu/rapid/pressrelease_MEMO-07-320_en.pdf.

- Finlay, L. (2008). Reflecting on "Reflective Practice". The Open University: Practice-based Professional Learning Centre. http://www.open.ac.uk/ opencetl/sites/www.open.ac.uk.opencetl/files/files/ecms/web-content/Finlay(2008)-Reflecting-on-reflective-practice-PBPL-paper-52.pdf.

- Jay, J. K., \& Johnson, K. L. (2002). Capturing complexity: a typology of reflective practice for teacher education. Teaching and Teacher Education, 18, 73-85. https://doi.org/10.1016/S0742-051X(01)00051-8.

- Leijena, Ä., Allasa, R., Toomb, A., Husuc, J., Mena Marcosd, J.J., Meijere, P., Knezice, D., Pedastea, M., \& Krulla, E. (2014). Guided reflection for supporting the development of student teachers' practical knowledge. Procedia - Social and Behavioral Sciences, 112, 314 - 322. https:// www.sciencedirect.com/science/article/pii/S1877042814011872. https:// doi.org/10.1016/j.sbspro.2014.01.1170.

- Mathew, P., Mathew, P., \& Peechattu, P. J. (2017). Reflective Practices: a OMeans to Teacher Development. Asia Pacific Journal of Contemporary 
Education and Communication Technology (APJCECT), vol. 3(1). www.apiar.org.au.

- Pollard, A. (2008). Reflective Teaching: evidence-informed professional practice (edi ia a treia). Londra: Continuum International Publishing Group.

- Pollard, A., \& Gougoulis, J.. (2002). The reflective teacher. Using action learning to improve teaching. Western Australian Department of Education and Training.

- Selmoa, L., \& Orsenigo, J. (2014). Learning and sharing through reflective practice in teacher education in Italy. Procedia - Social and Behavioral Sciences, 116, 1925 - 1929. https://www.sciencedirect.com/science/article/ pii/S1877042814005138. https://doi.org/10.1016/j.sbspro.2014.01.496.

- Tompkins, E. K. (2009). A Reflective Teaching Journal: An Instructional Improvement Tool for Academic Librarians. College \& Undergraduate Libraries. 16(4): 221-38. https://doi.org/10.1080/10691310903355937.

- Trif, L., \& Popescu, T. (2013). The reflective diary, an effective professional training instrument for future teachers. Procedia - Social and Behavioral Sciences, 93, 1070 - 1074. https://www.sciencedirect.com/science/article/ pii/S1877042813034356. https://doi.org/10.1016/j.sbspro.2013.09.332.

- Zalipour, A. (2015). Reflective practice. Teaching Development Unit, Wâhanga Whakapakari Ako. https://www.waikato.ac.nz/_data/assets/pdf_file/0006/ 360861/Reflective-Practice-June-2015.pdf.

- University of Southern Indiana. (2018). Reflective Teacher Model. http:// www.usi.edu/science/teacher-education/student-resources/reflective-teachermodel/.

The online version of this article can be found at: http://revped.ise.ro/category/2018-en/

\section{(cc) BV-NC-ZA}

This work is licensed under the Creative Commons Attribution-NonCommercial-ShareAlike 4.0 International License.

To view a copy of this license, visithttp://creativecommons.org/licenses/by-ncsa/4.0/ or send a letter to Creative Commons, $P O$ Box 1866, Mountain View, CA 94042, USA.
Versiunea online a acestui articol poate fi găsită la:http://revped.ise.ro/category/2018-ro/

\section{(CC) $\overline{B Y-N C-S A}$}

Această lucrare este licen iată sub Creative Commons Attribution-NonCommercial-ShareAlike 4.0 International License.

Pentru a vedea o copie a acestei licen e, vizita $i$ http://creativecommons.org/licenses/by-nc-sa/4.0/ sau trimite i o scrisoare către Creative Commons, PO Box 1866, Mountain View, CA 94042, SUA. 